\title{
BIODEGRADATION OF MONOAROMATIC HYDROCARBONS IN AQUIFER COLUMNS AMENDED WITH HYDROGEN PEROXIDE AND NITRATE
}

\author{
Paul J. Anid, Pedro J. J. Alvarez and Timothy M. Vogel* \\ Environmental and Water Resources Engineering, Department of Civil and Environmental Engineering, \\ The University of Michigan, Ann Arbor, MI 48109-2125, U.S.A.
}

(First received August 1991; accepted in revised form August 1992)

\begin{abstract}
The ability of indigenous microorganisms to degrade benzene, toluene, ethylbenzene and xylenes (BTEX) in laboratory scale flow-through aquifer columns was tested separately with hydrogen peroxide $(110 \mathrm{mg} / \mathrm{l})$ and nitrate $\left(330 \mathrm{mg} / \mathrm{l}\right.$ as $\left.\mathrm{NO}_{3}^{-}\right)$amendments to air-saturated influent nutrient solution. The continuous removal of individual components from all columns relative to the sterile controls provided evidence for biodegradation. In the presence of hydrogen peroxide, the indigeneous microorganisms degraded benzene and toluene (>95\%), meta- plus para-xylene $(80 \%)$ and ortho-xylene $(70 \%)$. Nitrate addition resulted in $90 \%$ removal of toluene and $25 \%$ removal of ortho-xylene. However, benzene, ethylbenzene, meta- and para-xylene concentrations were not significantly reduced after 42 days of operation. Following this experiment, low dissolved oxygen $(<1 \mathrm{mg} / \mathrm{l})$ conditions were initiated with the nitrate-amended column influent in order to mimic contaminated groundwater conditions distal from a nutrient injection well. Toluene continued to be effectively degraded (>90\%), and more than $25 \%$ of the benzene, $40 \%$ of the ethylbenzene, $50 \%$ of the meta-plus para-xylenes and $60 \%$ of the ortho-xylene were removed after several months of operation.
\end{abstract}

Key words-benzene, toluene, ethylbenzene, xylenes, biodegradation, electron acceptor, nitrate, hydrogen peroxide, aquifer, indigenous microbes

\section{INTRODUCTION}

Benzene, toluene, ethylbenzene and xylenes (BTEX) are often detected in groundwater at levels that exceed current water standards (Bitton and Gerba, 1984). The persistence of $B, T, E$ or $X$ at contaminated sites is often considered evidence of the lack of natural biological degradative processes. Many limitations, such as insufficient supply of electron acceptors (e.g. oxygen or nitrate), the absence of microbes with the required catabolic capacity, insufficient BTEX concentrations for induction of degradative enzymes and lack of proper nutrients, could cause the apparent absence of natural degradation. In laboratory studies, extensive BTEX biodegradation has been shown under aerobic (Alvarez et al., 1991; Alvarez and Vogel, 1991; Bayly and Barbour, 1984; Gibson and Subramaniam, 1984), denitrifying (Jensen et al., 1989; Hutchins, 1991; Hutchins et al., 1989, 1991; Kuhn et al., 1985, 1988; Major et al., 1988; Zeyer et al., 1986, 1990), dissimilatory iron-reducing (Lovely and Lonergan, 1990), sulfidogenic (Edwards et al., 1991) and methanogenic conditions (Grbić-Galić and Vogel, 1987; Vogel and Grbić-Galić, 1986; Wilson et al., 1986). The diversity of metabolic activity in situ and the effects of engineered manipulations, however, are not fully understood.

*Author to whom all correspondence should be addressed.
Often, in situ remediation schemes attempt to overcome particular limitations, such as the insufficient supply of electron acceptors discussed herein. Hydrogen peroxide, which dissociates into oxygen and water, is employed on occasion as a source of oxygen (Lee et al., 1988) because oxygen itself has a low aqueous solubility ( $\sim 10 \mathrm{mg} / 1$ under $1 \mathrm{~atm}$ of air). Recent studies have shown, however, that hydrogen peroxide can be toxic to some subsurface microorganisms at concentrations as low as $0.003 \%$ (Pardieck et al., 1990). In addition, bacterial decomposition of hydrogen peroxide could prevent its transport in groundwater to contaminated areas (Spain et al., 1989). Hydrogen peroxide can also oxidize ferrous iron and precipitate ferric oxide, which may lead to clogging of well screens and reduction of soil permeability (Lee et al., 1988), although those problems can be site specific (Morgan and Watkinson, 1992). In theory, nitrate could be used as a terminal electron acceptor during BTEX oxidation by facultative denitrifying bacteria after dissolved oxygen has been sufficiently reduced by aerobic respiration. Addition of nitrate might result in an increase in the extent of in situ BTEX degradation due to its higher solubility and better perfusion characteristics relative to oxygen. Circumstantial evidence for the benefit of nitrate as a supplemental electron acceptor comes from on-site remediation efforts in West Germany (Battermann 
and Werner, 1984), Canada (Lemon et al., 1989) and U.S.A. (Downs et al., 1989; Sheehan et al., 1988; Wilson, 1991a), where the addition of nitrate to contaminated groundwater apparently enhanced the biodegradation of BTEX compounds. The saturated subsurface environment of many aquifers has been shown to contain active denitrifiers (Kukor and Olsen, 1989; Tiedje, 1988). Yet, the ubiquity of denitrifiers that are specifically capable of degrading BTEX in the subsurface environment has not been established.

Studies with nitrate-reducing enrichments (Evans et al., 1991a; Hutchins et al., 1991; Hutchins, 1991) and pure cultures (Evans et al., 1991b) have shown that toluene and xylenes, but not benzene, can be degraded by indigenous denitrifying microbes. Other studies, however, have reported benzene degradation under denitrifying conditions (Jensen et al., 1989; Major et al., 1988). These laboratory studies were performed in microcosms, in which conditions of exposure are controlled by completely mixed dynamics versus the dispersive plug-flow hydraulic regime of natural aquifer environments. Continuousflow columns mimic flow in aquifer systems and, hence, are better tools for understanding the operative processes and their limitations. Degradation of toluene and xylenes has been reported under denitrifying conditions in laboratory aquifer columns (Kuhn et al., 1985, 1988; Zeyer et al., 1986). However, no column study has yet addressed the relative effectiveness of adding nitrate or hydrogen peroxide to the same aquifer material.

The study described here explored potential treatment techniques for BTEX contaminated aquifers by directly comparing the influence of amending flow-through aquifer columns with either electron acceptor, nitrate or oxygen derived from hydrogen peroxide. The experimental system attempted to mimic actual groundwater cleanup efforts by using only indigenous microbes associated with aquifer material. Influent to columns contained either oxygen levels to mimic hydrocarbon-contaminated groundwater distal to nutrient injection wells.

\section{MATERIALS AND METHODS}

\section{Site and sampling}

Aquifer material was collected beneath a gas plant in Northern Michigan, U.S.A. with a sterilized split-spoon sampler and plastic coring tubes. The sample used in the column studies was collected from the unsaturated zone (3-8 $\mathrm{ft}$ deep). The level of groundwater contamination was approx. $200 \mathrm{mg} / 1$ total BTEX. The aquifer material consisted primarily of medium sized sand with low organic carbon content (0.03-0.08\%) (Chiang et al., 1989).

\section{Continuous-flow column system}

Sterile glass columns ( $58 \mathrm{~cm}$ long, $2.2 \mathrm{~cm}$ i.d.) equipped with six sampling ports were packed with aquifer material as described by Siegrist and McCarty (1987). Each column received a BTEX-enriched mineral medium containing basic inorganic nutrients described previously (Alvarez $e t$ al., 1991). The influent total BTEX concentration was approx.
$60 \mathrm{mg} / \mathrm{l}: 20 \mathrm{mg} / 1$ benzene, $20 \mathrm{mg} / 1$ toluene, $3 \mathrm{mg} / \mathrm{l}$ ethylbenzene, $4 \mathrm{mg} / \mathrm{l}$ ortho-xylene and $13 \mathrm{mg} / \mathrm{l}$ meta- plus paraxylenes.

In the first experiment, the biodegradation of benzene, toluene and xylenes was studied under two supplemental electron acceptor conditions: (1) hydrogen peroxide amendment (110 mg/l into one pair of columns) and (2) nitrate amendment ( $330 \mathrm{mg} / \mathrm{h}$ into a second pair of columns) with influent saturated with dissolved oxygen from air $(9 \mathrm{mg} / \mathrm{l})$. Two control columns, autoclaved for $4 \mathrm{~h}$ at $120^{\circ} \mathrm{C}$, received the BTEX-enriched mineral medium with hydrogen peroxide $(110 \mathrm{mg} / \mathrm{l})$, nitrate $(330 \mathrm{mg} / \mathrm{l})$ and sodium azide $(2 \mathrm{~g} / \mathrm{l})$ as a microbial inhibitor. Columns were fed continuously in an upflow mode over a 42 day period at a rate of $2 \mathrm{ml} / \mathrm{h}$ using Harvard Model 22 syringe pumps equipped with $50 \mathrm{ml}$ gas-tight glass and Teflon syringes (Hamilton Co., Reno, Nev.) (Fig. 1).

A second experiment with low concentrations of influent dissolved oxygen was performed to mimic hydrocarboncontaminated groundwater distal from the injection well. A nitrate-amended column used in the first experiment was placed in an anaerobic glove box at $25^{\circ} \mathrm{C}$ for a 45 -day period. A control column receiving no supplemental nitrate was also placed inside the box. Oxygen was eliminated from the glove box by using heated $\mathrm{H}_{2}$ and palladium catalyst pellets. A hydrogen-nitrogen $(1 / 9 \mathrm{v} / \mathrm{v})$ atmosphere was maintained in the glove box. A gas analyzer, Coy Model 10 (Coy, Ann Arbor, Mich.) was used to monitor $\mathrm{O}_{2}$ and $\mathrm{H}_{2}$ levels in the box. The dissolved oxygen in the influent media was lowered below $1 \mathrm{mg} / \mathrm{l}$ by simultaneously heating and sparging it with oxygen-free nitrogen gas for more than $60 \mathrm{~min}$, including $15 \mathrm{~min}$ of active boiling.

\section{Analytical procedures}

Effluent samples $(0.5 \mathrm{ml})$ were collected for BTEX analysis with gas-tight syringes (No. 1002, Hamilton Co., Reno, Nev.) from a switching valve located on the steel tubing connected to the effluent end of the column. Each sample was placed in a $5 \mathrm{ml}$ vial, capped with a 20 -mm Tefloncoated septum (Hewlett-Packard Co., Palo Alto, Calif.) and sealed with an aluminum cap. The vials were placed into a headspace sampler, HP 19395A (Hewlett-Packard Co.) and equilibrated at $35^{\circ} \mathrm{C}$. The sampler was connected to an $\mathrm{HP}$ 5890 gas chromatograph (GC) (Hewlett-Packard Co.) containing a 30-m Megabore HP 5 column and equipped with a flame ionization detector (FID). The FID was connected to an HP 300 HPGC with Chem Station software to

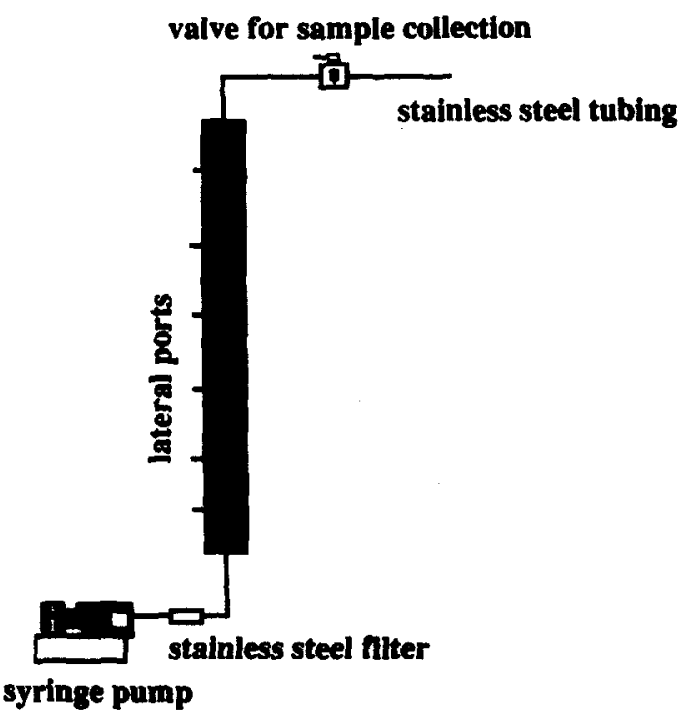

Fig. 1. Laboratory apparatus for flow-through aquifer columns. 
integrate the signal. The analytical precision, assessed by the coefficient of variation (i.e. standard deviation divided by mean) was approx. $10 \%$ including variations in sample collection. The limit of detection of this procedure was approx. $0.01 \mathrm{ppm}$ for each of the BTEX compounds.

During initial tracer experiments, bromide was used to determine dispersion, potential sorption of the monoaromatics, liquid detention time and to confirm pore volume in the packed columns. Bromide and nitrate were analyzed with a Dionex 4500i ion chromatograph (Dionex Inc., Sunnyvale, Calif.). Samples for dissolved oxygen (DO) measurements were analyzed with a biological oxygen monitor YSI 530, which was equipped with a micro chamber assembly and an oxygen micro probe (YSI Inc., Yellow Spring, Ohio).

\section{RESULTS}

The bromide tracer results indicate a porosity of approx. $38 \%$. The superficial velocity in the packed columns was $0.53 \mathrm{~cm} / \mathrm{h}$, corresponding to an average pore velocity of $1.4 \mathrm{~cm} / \mathrm{h}$. The dispersion coefficient was estimated to be $3.1 \mathrm{~cm}^{2} / \mathrm{h}$ from the bromide breakthrough curve by fitting the data to an advection/dispersion transport solution (van Genuchten and Parker, 1984). Approximately 4.6 days were required to displace one bed volume.

During the first 42-day experiment, benzene was degraded (greater than $90 \%$ removal) only in the hydrogen peroxide-fed soil columns [Fig. 2(A)]. In both the nitrate-fed columns and sterile control columns, benzene concentrations in the column effluent reached influent levels after 15 days of operation [Fig. 2(B)]. The benzene in the effluent of the nitratefed columns did, however, reach influent levels slower than the sterile columns as indicated by effluent benzene concentrations remaining below $65 \%$ of influent concentrations in nitrate-fed columns during the first 10 days of operation [Fig. 2(B)]. Effluent
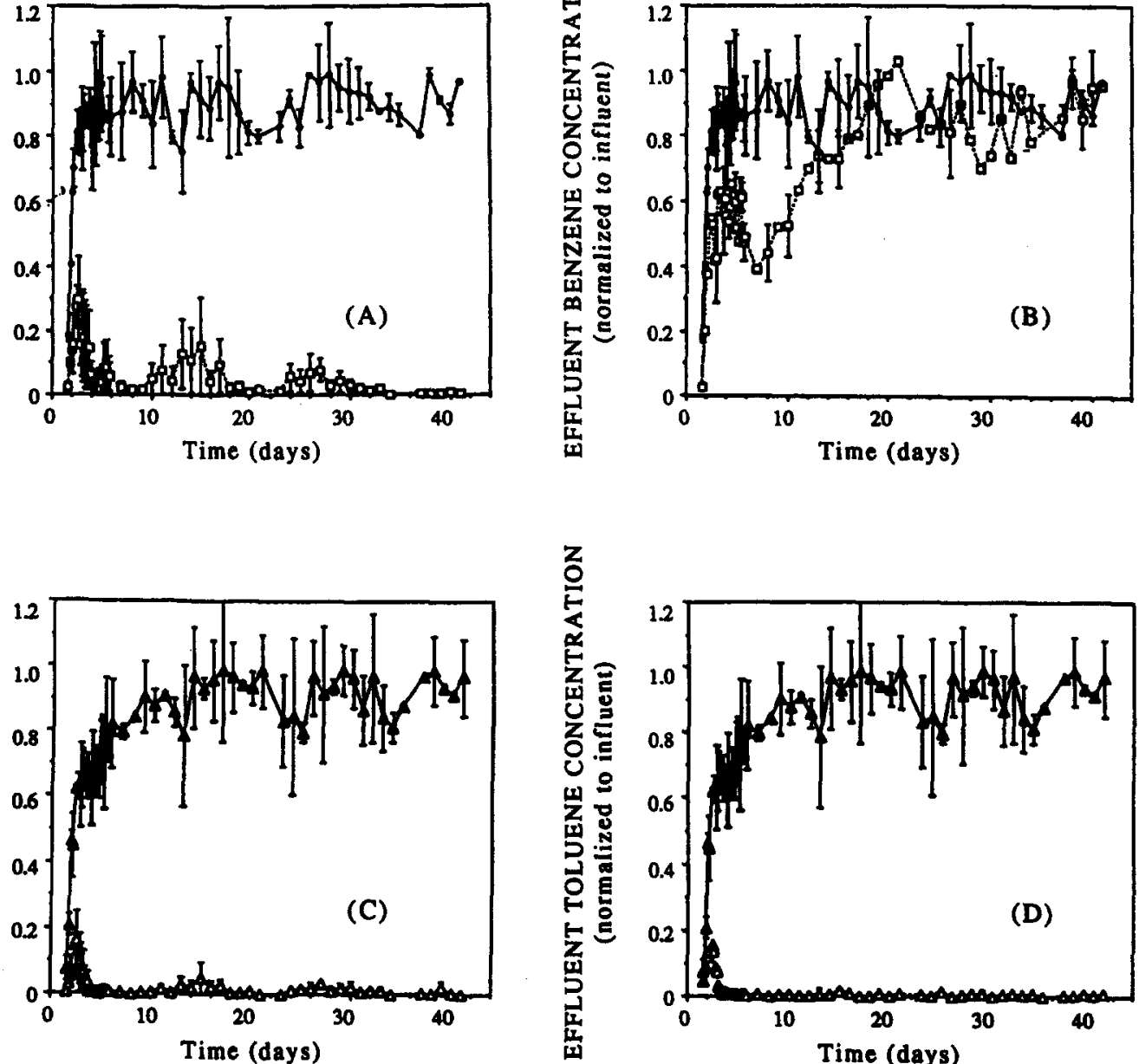

Fig. 2. Concentrations of benzene $(\square)$ and toluene $(\Delta)$ in the continuous-fiow aquifer columns effluent, relative to the influent concentration of BTX $(20 \mathrm{mg} / 1$ each), are plotted versus time as the mean of two replicate columns with standard deviation bars. Columns amended with hydrogen peroxide (110 mg/l) $(A, C)$ and nitrate $(330 \mathrm{mg} / 1)(B, D)$, and sterile control columns are shown (, , toluene; $O$, benzene). All columns had an influent oxygen concentration of approx. $9 \mathrm{mg} / \mathrm{l}$. Results without error bars represent data from only one column. 
benzene concentrations from sterile controls reached influent levels in about 5 days.

Unlike benzene, toluene was significantly degraded in both hydrogen peroxide (greater than $95 \%$ removal) [Fig. 2(C)] and nitrate-fed columns (greater than $90 \%$ removal) [Fig. 2(D)]. Toluene was not degraded in sterile control columns in which effluent concentrations reached influent levels after about 10 days [Fig. 2(C) and (D)]. In both hydrogen peroxidefed columns and nitrate-fed columns, toluene started to break through as the ratio of effluent to influent $\left(C / C_{0}\right)$ reached 0.16 at about 3 days, and then biodegradation reduced the effluent concentration.

Meta-plus para-xylenes were removed by about $80 \%$ in hydrogen peroxide-fed columns but not in nitrate-fed columns. Alternatively, ortho-xylene was removed by $70 \%$ in the hydrogen peroxide-fed column, yet, showed slight $(25 \%)$ removal in the nitrate-fed column after about 30 days (data not shown). Nitrate consumption in the latter columns averged $164 \mathrm{mg} / \mathrm{l}$ at this time. The possibility of oxygen diffusion into the columns cannot be excluded since levels of oxygen in the effluents of the nitrate-fed and the hydrogen peroxide-fed columns never dropped below $2 \mathrm{mg} / \mathrm{l}$.

In the nitrate-fed column, with reduced oxygen concentration in the influent, toluene was still degraded by greater than $95 \%$, but now some benzene degradation had begun (Fig. 3). The concentration profiles showed that benzene was mainly degraded in the latter half of the column (Fig. 4). In addition, the profiles for ethylbenzene, meta- plus para-xylenes and ortho-xylene indicated 40,50 and $60 \%$ degradation, respectively, considering that sterile control columns showed BTEX losses on the order of $10 \%$ (Fig. 4). Nitrate consumption in this column was 53 and $78 \%$ after 30 and 45 days, respectively.

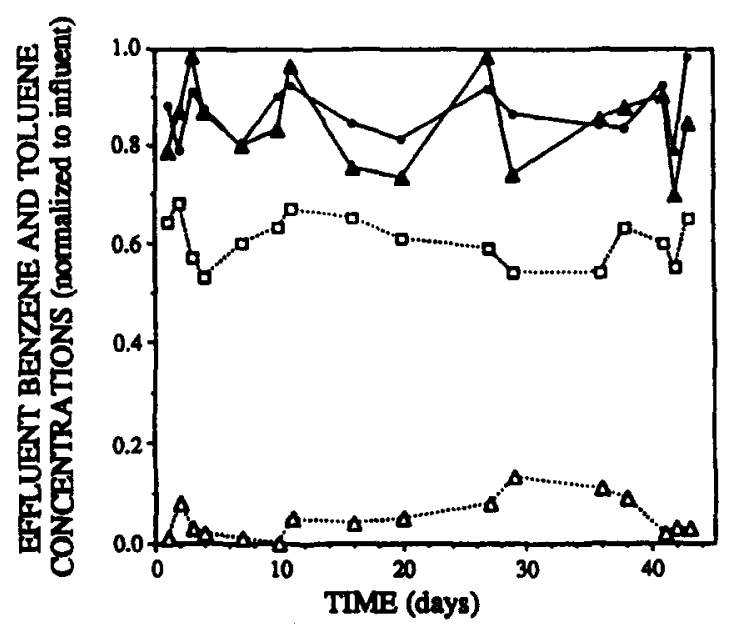

Fig. 3. Concentrations of benzene $(\square)$ and toluene $(\Delta)$ in the continuous-flow aquifer column efiluent, relative to the influent concentration ( $20 \mathrm{mg} / \mathrm{leach}$ ) from column amended with nitrate $(330 \mathrm{mg} / \mathrm{h})$ and sterile control $(\Delta$, toluene; $\boldsymbol{O}$, benzene), both with low oxygen concentration in influent $(<\mathrm{lmg} / \mathrm{l})$.
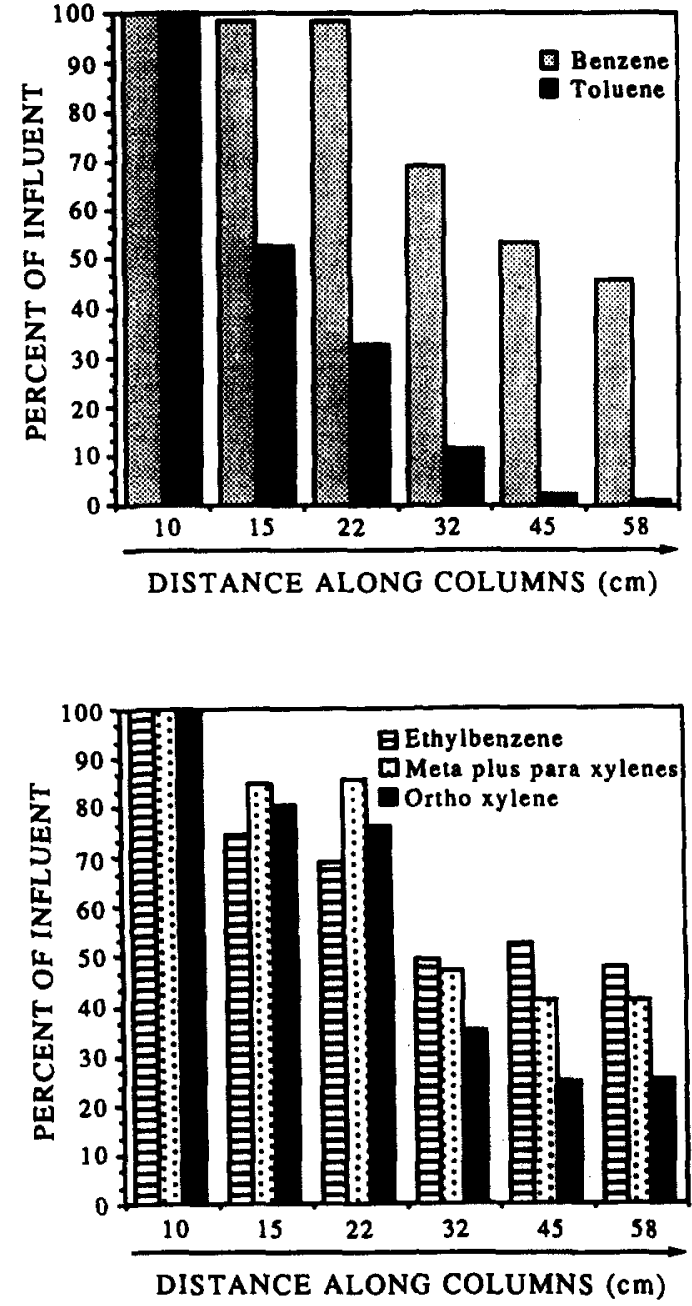

Fig. 4. Concentration profiles of aromatic hydrocarbons, normalized to influent concentrations, in the nitrateamended column (after 45 days of continuous operation) with low oxygen influent $(<1 \mathrm{mg} / \mathrm{l})$. Losses in control columns reached about $10 \%$ by $58 \mathrm{~cm}$. Influent BTEX concentrations were $20 \mathrm{mg} / 1$ benzene, $20 \mathrm{mg} / \mathrm{l}$ toluene, $3 \mathrm{mg} / \mathrm{l}$ ethylbenzene, $4 \mathrm{mg} / \mathrm{l}$ ortho-xylene and $13 \mathrm{mg} / \mathrm{l}$ meto plus para-xylenes.

\section{DISCUSSION}

The complete oxidation of the benzene $(20 \mathrm{mg} / \mathrm{l})$, toluene $(20 \mathrm{mg} / \mathrm{l})$ and ethylbenzene plus xylenes $(20 \mathrm{mg} / \mathrm{l})$ fed to the aquifer columns, would require $61.5,62.6$ and $63.4 \mathrm{mg} / 1$ of oxygen, respectively, based on the following stoichiometric equations (on a one electron basis):

$$
\begin{gathered}
\text { B: } \frac{1}{30} \mathrm{C}_{6} \mathrm{H}_{6}+\frac{1}{4} \mathrm{O}_{2} \rightarrow \frac{1}{5} \mathrm{CO}_{2}+\frac{1}{10} \mathrm{H}_{2} \mathrm{O} \\
\text { T: } \frac{1}{36} \mathrm{C}_{7} \mathrm{H}_{8}+\frac{1}{4} \mathrm{O}_{2} \rightarrow \frac{7}{36} \mathrm{CO}_{2}+\frac{1}{9} \mathrm{H}_{2} \mathrm{O} \\
\text { E, X: } \frac{1}{42} \mathrm{C}_{8} \mathrm{H}_{10}+\frac{1}{4} \mathrm{O}_{2} \rightarrow \frac{8}{42} \mathrm{CO}_{2}+\frac{3}{42} \mathrm{H}_{2} \mathrm{O} .
\end{gathered}
$$

Alternatively, the complete oxidation of benzene $(20 \mathrm{mg} / \mathrm{l})$, toluene $(20 \mathrm{mg} / 1)$ and ethylbenzene plus xylenes $(20 \mathrm{mg} / \mathrm{l})$ would require $95.4,97.0$ and $98.2 \mathrm{mg} / 1$ nitrate based on the complete reduction of 
nitrate to nitrogen gas (on a one electron basis):

$$
\begin{aligned}
& \text { B: } \frac{1}{30} \mathrm{C}_{6} \mathrm{H}_{6}+\frac{1}{5} \mathrm{NO}_{3}^{-}+\frac{1}{5} \mathrm{H}^{+} \rightarrow \frac{1}{10} \mathrm{~N}_{2}+\frac{1}{5} \mathrm{H}_{2} \mathrm{O}+\frac{1}{5} \mathrm{CO}_{2} \\
& \text { T: } \frac{1}{36} \mathrm{C}_{7} \mathrm{H}_{8}+\frac{1}{5} \mathrm{NO}_{3}^{-}+\frac{1}{5} \mathrm{H}^{+} \rightarrow \frac{1}{10} \mathrm{~N}_{2}+\frac{19}{90} \mathrm{H}_{2} \mathrm{O}+\frac{7}{36} \mathrm{CO}_{2} \\
& \text { E, X: } \begin{array}{r}
\frac{1}{42} \mathrm{C}_{8} \mathrm{H}_{10}+\frac{1}{5} \mathrm{NO}_{3}^{-} \\
\quad+\frac{1}{5} \mathrm{H}^{+} \rightarrow \frac{1}{10} \mathrm{~N}_{2}+\frac{23}{105} \mathrm{H}_{2} \mathrm{O}+\frac{8}{42} \mathrm{CO}_{2} .
\end{array}
\end{aligned}
$$

In this study, biodegradation refers to the loss of the monoaromatic compounds as a result of microbial action. No attempts were made to analyze for the metabolites or end products of oxidation and denitrification. Therefore, our data cannot determine the extent to which the electron acceptors added to the columns are used for the complete biotransformation of BTEX into $\mathrm{CO}_{2}, \mathrm{H}_{2} \mathrm{O}$ and $\mathrm{N}_{2}$, or utilized in an initial step that leads to the accumulation of BTEX metabolites. Regardless of the transformation products, B, T, E and $X$ were not removed to the same extent in sterile columns and under different electron acceptor amendments. The complete breakthrough of benzene and the slight toluene retardation in sterile columns indicate that sorption played a minor role in this study, probably as a result of the low organic matter content $(0.03-0.08 \%)$ of the aquifer material. In aquifer columns receiving hydrogen peroxide, benzene and toluene were almost completely degraded. Hence, hydrogen peroxide, reportedly toxic in mixed batch studies but tolerated when fed into soil columns (Pardieck et al., 1990), was effectively used as a source of oxygen in our flow-through aquifer columns. Also, the concentration of hydrogen peroxide used in this study $(0.011 \%)$ is below the $0.05 \%$ toxicity limit reported by Lee et al. (1988). Other studies have also shown that an incremental increase in hydrogen peroxide levels allows microbial populations to tolerate concentrations up to $0.05 \%$ in a column experiment (Flathman et al., 1991) and up to $0.1 \%$ in an in situ bioremediation application (Wilson, 1991b). In comparison with nitrate-amended aquifer columns, the hydrogen peroxide-amended columns exhibited more removal of BTEX. Except for an initial phase of benzene removal probably related to residual oxygen present in the aquifer material, the nitrateamended columns only exhibited similar degradation efficiency for toluene, but were relatively ineffective in removing benzene, ethylbenzene or xylenes. The influence of supplemental electron acceptor extends, therefore, past the issue of providing a sufficient amount of electron acceptor for BTEX degradation to the issue of microbial ecology.

The amount of nitrate utilized during BTEX degradation $(164 \mathrm{mg} / \mathrm{l})$ in the first experiment suggests that nitrate was used as terminal electron acceptor. Theoretically, $92 \mathrm{mg} / \mathrm{l}$ nitrate are needed to completely oxidize $95 \%$ of the influent toluene, provided that complete nitrate reduction to nitrogen gas is accomplished. The additional removal of nitrate $(72 \mathrm{mg} / \mathrm{l})$ might have been due to either incomplete reduction of nitrate to $\mathrm{N}_{2}$ gas, some xylene degradation, cell growth or use by denitrifiers that consumed naturally-occurring orgainc matter. The influent media contained $100 \mathrm{mg} / \mathrm{l}$ of ammonium chloride, so that the use of nitrate as a nitrogen source for anabolic requirements is unlikely. The degree to which nitrate was reduced to nitrogen gas or nitrite was not determined in this study.

Another ecological issue is related to the presence of oxygen $(2 \mathrm{mg} / \mathrm{l})$ in the effluent of the nitrate amended columns. Biochemical and thermodynamic considerations suggest that nitrate cannot be used as an electron acceptor concurrently with oxygen by the same microorganisms. However, recent evidence has indicated that denitrification in aerobic environments is possible for a few strains. For example, Alcaligenes sp. (Krull and Veeningen, 1977) used nitrate and oxygen at the same time when grown in a batch even at air saturation above $\mathbf{2 0 0 \%}$. Klebsiella (Dunn et al., 1979), Hyphomicrobium (Meiberg et al., 1980) and Escherichia coli E4 (Brons and Zhender, 1990) still contained significant nitrate reductase activity when grown in chemostat at 10,35 and $90 \%$ saturation, respectively. Most of these denitrifiers were isolated from municipal waste processing units where the excess of electron donor and the fluctuating status of nitrate and oxygen select for organisms that can make simultaneous use of both electron acceptors. It is therefore possible that our nitrate-amended columns contained organisms with dual electron acceptor based respiration. The likelihood of aerobic denitrification is further enhanced by the dispersive flow regime in the columns that could have facilitated the development of spatial gradients with respect to BTEX and electron acceptors, as well as temporal discontinuities that might result in the development of anaerobic niches within aerobic environments. These ecological heterogeneities were also shown to permit denitrification to occur in aerobic sectors of aquifers (Hopner et al., 1990; Hutchinson and Mosier, 1979; Thomas and Ward, 1989).

Toluene and all xylene isomers have been reported to be degraded under denitrifying conditions (Evans et al., 1991a; Jensen et al., 1989; Hutchins, 1991; Hutchins et al., 1991; Kuhn et al., 1985). While benzene degradation under denitrifying conditions has been reported in laboratory (Major et al., 1988; Jensen et al., 1989) and field studies (Battermann and Werner, 1984), its recalcitrance in other laboratory (Evans et al., 1991a, 1991b; Kuhn et al., 1988; Hutchins et al., 1991) and field aquifer studies (Hutchins et al., 1989; Wilson et al., 1989) has also been observed. The ability of the nitrate-amended columns in our first experiment to selectively remove toluene, but not benzene, is consistent with that shown in batch denitrifying enrichments obtained from the same site (Evans et al., 1991a). Hence, the potential for nitrate as an effective supplemental electron acceptor for BTEX degradation is considerably reduced if it will not ameliorate benzene contamination. 
Nevertheless, in the second experiment, benzene and xylenes were partially degraded in the nitrateamended column with low influent oxygen concentrations after several months of operation (Fig. 3). The influent dissolved oxygen $(<1 \mathrm{mg} / \mathrm{l})$ would have to be much higher to account even for the observed $25 \%$ degradation of benzene. The nitrate consumption $(270 \mathrm{mg} / \mathrm{l})$ exceeds the maximum stoichiometric requirement for toluene alone $(230 \mathrm{mg} / \mathrm{l})$ even assuming that all of the nitrate was reduced only to nitrite. Significant assimilatory nitrate reduction is unlikely as ammonium chloride $(100 \mathrm{mg} / \mathrm{l})$ was also added. Thus, circumstantial evidence for the participation of denitrifiers in benzene degradation was obtained. However, an attempt to establish enrichment cultures of denitrifying bacteria was successful using toluene as sole carbon and energy source, but not using benzene alone. This suggests that benzene loss might not be directly due to nitrate-based respiration or that toluene degraders transformed benzene cometabolically.

In any case, the reason for the slowly increasing removal of benzene and, to a lesser degree, xylenes over time in the aquifer columns is still unclear. Perhaps, the anaerobic indigenous microorganisms, after a long period of exposure, acquired the ability to metabolize all BTEX compounds. Another possible explanation for the removal of benzene is the presence of fermentative activity that might have developed with time in the column. Although benzene degradation under methanogenic or fermentative conditions has been reported (Grbić-Galić and Vogel, 1987; Vogel and Grbić-Galić, 1988; Wilson et al., 1986), the rates are probably too slow to explain our observations.

\section{SUMMARY AND CONCLUSIONS}

This study compared the influence of hydrogen peroxide and nitrate amendments to aquifer columns on the biodegradation of BTEX by indigenous bacteria. The addition of hydrogen peroxide or nitrate allowed for the nearly complete removal of toluene. Benzene and xylenes were degraded significantly with hydrogen peroxide amendment, but not initially with nitrate amendment. Nevertheless, benzene and xylenes were partially removed after several months of operation in nitrate-amended columns with influent low oxygen concentrations. This suggests the potential benefit of injecting nitrate to enhance in situ bioremediation of BTEXcontaminated aquifers where hydrogen peroxide addition proves unfeasible.

Acknowledgements - We gratefully acknowiedge the technical assistance of Andy Chu and Thomas Yavaraski. This work was supported in part by the Michigan Oil and Gas Association (DRDA No. 90-1112), the NIEHS Superfund Research Center (Grant No. 5 P42 ESO4911-03) and the Office of Research and Development, U.S. Environmental Protection Agency to the Great Lakes and Mid-
Atlantic Hazardous Substance Research Center (Grant No. R-815750-02). Partial funding of the research activities of the Center is also provided by the State of Michigan Department of Natural Resources. The content of this publication does not necessarily represent the views of any agency.

\section{REFERENCES}

Alvarez P. J. J. and Vogel T. M. (1991) Substrate interactions of benzene, toluene, and para-xylene during microbial degradation by pure cultures and mixed culture aquifer slurries. Appl. envir. Microbiol. 57, 2981-2985.

Alvarez P. J. J., Anid P. J. and Vogel T. M. (1991) Kinetics of biodegradation of benzene and toluene in sandy aquifer material. Biodegradation 2, 43-51.

Battermann G. and Werner P. (1984) Beseitung einer untergrunkontamination mit kohlwasserstoffen durch mikrobiellen abbu. Gndwassforch.-Wass./Abwass. 125, 366-373.

Bayly R. C. and Barbour M. G. (1984) The degradation of aromatic compounds by the meta and gentisate pathways. In Microbial Degradation of Organic Compounds (Edited by Gibson D. T.), pp. 253-294. Dekker, New York.

Bitton G. and Gerba C. P. (1984) Groundwater pollution microbiology: the emerging issue. In Groundwater Pollution Microbiology (Edited by Bitton G. and Gerba C. P.), p. 1. Wiley, New York.

Brons H. J. and Zehnder A. J. B. (1990) Aerobic nitrate reduction in continuous cultures of Escherichia coli E4. Arch. Microbiol. 153, 531-536.

Chiang C. Y., Salanitro J. P., Chai E. Y., Colthart J. D. and Klein (1989) Aerobic biodegradation of benzene, toluene and xylene in a sandy aquifer-data analysis and computer modeling. Gnd Wat. 27, 823-834.

Downs W. C., Hutchins S. R., Wilson J. T., Douglas R. H. and Hendrix D. J. (1989) Pilot project on biorestoration of fuel-contaminated aquifer using nitrate: Part I-Field design and groundwater modeling. In Proceedings of the Conference on Petroleum Hydrocarbons and Organic Chemicals in Groundwater: Prevention, Detection and Restoration, Houston, Tex., 15-17 November, pp. 219-233.

Dunn G. M., Herbert R. A. and Brown C. M. (1979) Influence of oxygen tension on nitrate reduction by a Klebsiella sp. growing in a chemostat culture. J. gen. Microbiol. 112, 379-383.

Edwards E., Wills L., Grbić-Galić D. and Reinhard M. (1991) Anaerobic degradation of toluene and xylene -implications of sulfate as the terminal electron acceptor. In In Situ Bioreclamation: Processes for Xenobiotic and Hydrocarbon Treatment (Edited by Hinchee R. E. and Olfenbuttel R. F.), pp. 463-470. ButterworthHeinemann, Stoneham, Mass.

Evans P. J., Mang D. T. and Young L. Y. (1991a) Degradation of toluene and $m$-xylene and transformation of $o$-xylene by denitrifying enrichment cultures. Appl. envir. Microbiol. 57, 450-454.

Evans P. J., Mang D. J., Kim K. S. and Young L. Y. (1991b) Anaerobic degradation of toluene by a denitrifying bacterium. Appl. envir. Microbiol. 57, 1139-1145.

Flathman P. E., Carson J. H. Jr, Whitehead S. J., Khan K. A., Barnes D. M. and Evans J. S. (1991) Laboratory evaluation of the utilization of hydrogen peroxide for the enhanced biological treatment of petroleum hydrocarbon contaminants in soil. In In Situ Bioreclamation: Processes for Xenobiotic and Hydrocarbon Treatment (Edited by Hinchee R. E. and Olfenbuttel R. F.), pp. 125-142. Butterworth-Heinemann, Stoneham, Mass.

van Genuchten M. Th. and Parker J. C. (1984) Boundary conditions for displacement experiments through short laboratory soil column. Soil. Sci. Soc. Am. J. A , 703-708. 
Gibson D. T. and Subramanian (1984) Microbial degradation of aromatic hydrocarbons. In Microbial Degradation of Organic Compounds (Edited by Gibson D. T.), pp. 181-252. Dekker, New York.

Grbić-Galić D. and Vogel T. M. (1987) Transformation of toluene and benzene by mixed methanogenic cultures. Appl. envir. Microbiol. 53, 254-260.

Hopner T., Harder H., Kieswetler K., Dalyan U., KutscheSchietenknop 1. and Teigelkamp B. (1989) Biochemical aspects of hydrocarbon biodegradation in sediments and soils. In Toxic Chemicals in Porous Media (Edited by Gerstl Z., Chen Y., Mingergrin and Yaron B.), pp. 251-271. Springer, New York.

Hutchins R. S. (1991) Biodegradation of monoaromatic hydrocarbons using oxygen, nitrate or nitrous oxide as terminal electron acceptor. Appl. envir. Microbiol. 57, 2403-2407.

Hutchins R. S., Sewell G. W., Kovacs D. A. and Smith G. A. (1991) Biodegradation of aromatic hydrocarbons by aquifer microorganisms under denitrifying conditions. Envir. Sci. Technol. 25, 68-76.

Hutchins R. S., Wilson J. T., Douglass R. H. and Hendrix D. J. (1989) Field and laboratory evaluation of the use of nitrate to remove BTX from a fuel spill. In Proceedings: Environmental Research Conference on Groundwater Quality and Waste Disposal (Edited by Murarka I. P. and Cordle S.), 2-4 May. Washington, D.C.

Hutchinson G. L. and Mosier A. R. (1979) Nitrous oxide emissions from an irrigated corn field. Science 205 , 1125-1126.

Jensen B. K., Arvin E. and Gundersen T. (1990) Biodegradation of phenolic compounds and monoaromatic hydrocarbons by a mixed wastewater culture under denitrifying conditions. In Organic Contaminants in Wasterwater, Sludge and Sediment: Occurrence, Fate and Disposal (Edited by Quagherbeur D., Temmerman I. and Angeletti G.). Elsevier Applied Science, New York.

Krull J. M. and Veeningen R. (1977) The synthesis of dissimilatory nitrate reductase under aerobic conditions in a number of denitrifying bacteria isolated from activated sludge and drinking water. Wat. Res. 11, 39-43.

Kuhn E. P., Zeyer J., Eicher P. and Schwarzenbach R. P. (1988) Anaerobic degradation of alkylated benzenes in denitrifying laboratory aquifer columns. Appl. envir. Microbiol. 54, 490-496.

Kuhn E. P., Colberg P. J., Schnoor J. L., Wanner O, Zehnder A. J. B. and Schwarzenbach R. P. (1985) Microbial transformation of substitute benzenes during infiltration of river water to groundwater: laboratory column studies. Envir. Sci. Technol. 19, 961-967.

Kukor J. J. and Olsen R. H. (1989) Diversity of toluene degradation following long term exposure to BTEX in situ. In Biotechnology and Biodegradation (Edited by Kamely D., Chakrabarty A. and Omenn G.), pp. 405-421.

Lee M. D., Thomas J. M., Borden R. C., Bedient P. B., Ward C. H. and Wilson J. T. (1988) Biorestoration of aquifers contaminated with organic compounds. $C R C$ Crit. Rev. envir. Control 18, 29-89.

Lemon L. A., Barbaro J. R. and Barker J. F. (1989) Biotransformation of BTEX under anaerobic denitrifying conditions: evaluation of field observations. In Proceedings of the FOCUS Conference on Eastern Regional Groundwater Issues. Kitchener, Ontario, Canada.

Lovely D. R. and Lonergan D. J. (1990) Anaerobic oxidation of toluene, phenol and $p$-cresol by the dissimilatory iron-reducig organism GS-15. Appl, envir. Microbiol. S6, 858-864.

Major D. W., Mayfield C. I. and Barker J. F. (1988) Biotransformation of benzene by denitrification in aquifer sand. Gnd Wat. 26, 8-14.
Meiberg J. B. M., Bruinenberg P. M. and Harder W. (1980) Effect of dissolved oxygen tensions of the metabolism of methylated amines in Hyphomicrobium $\chi$ in the absence and presence of nitrate. J. gen. Microbiol. 120, 453-463.

Morgan P. and Watkinson R. J. (1992) Factors limiting the supply and efficiency of nutrient and oxygen supplements for the in situ biotreatment of contaminated soil and groundwater. Wat. Res. 26, 73-78.

Pardieck D. L., Bouwer E. J. and Stone T. L. (1990) Hydrogen peroxide as a source of oxidant capacity for the biotransformation of benzene, toluene and xylene in biofilm. In Environmental Engineering Proceedings of the 1990 Specialty Conference. American Society of Civil Engineers, New York.

Sheehan P. J., Schneiter R. W., Mohr T. K. G. and Gersberg R. M. (1988) Bioreclamation of gasoline contamination without oxygen addition. In Proceedings of the Second National Outdoor Action Conference on Aquifer Restoration, Groundwater Monitoring, and Geophysical Methods, Vol. 1, pp. 183-199, 23-26 May, National Water Works Association, Las Vegas, Nev.

Siegrist H. and McCarty P. L. (1987) Column methodologies for determining sorption and biotransformation potential for chlorinated aliphatic compounds in aquifers. J. Contam. Hydrol. 2, 31-50.

Spain J. C., Milligan J. D., Downey D. C. and Slaughter J. K. (1989) Excessive bacterial decomposition of $\mathrm{H}_{2} \mathrm{O}_{2}$ during enhanced biodegradation. Gnd Wat. 27, 163-167.

Thomas J. M. and Ward C. H. (1989) In situ biorestoration of organic contaminants in the subsurface. Envir. Sci. Technol. 23, 760-766.

Tiedje J. M. (1988) Ecology of denitrification and dissimilatory nitrate reduction to ammonium. In Biology of Anaerobic Microarganisms (Edited by Zhender A. J. B.), pp. 179-244. Wiley, New York.

Vogel T. M. and Grbić-Galić D. (1986) Incorporation of oxygen from water into toluene and benzene during anaerobic fermentation transformation. Appl. envir. Microbiol. 52, 200-202.

Wilson J. (1991a) Two jet fuel cleanup evaluations under bioremediation field initiative. In Bioremediation in the Field, pp. 1-5. U.S. Environmental Protection Agency, EPA/540/2-91/018.

Wilson J. (1991b) Nitrate enhanced bioremediation restores fuel contaminated groundwater to drinking water standard. In Bioremediation in the Field, pp. 1-2. U.S Environmental Protection Protection Agency, EPA/540/ M-91/002.

Wilson B. H., Smith G. B. and Rees J. F. (1986) Biotransformation of selected alkylbenzenes and halogenated aliphatic hydrocarbons in methanogenic aquifer material: a microcosm study. Envir. Sci. Technol. 20, 997-1002.

Wilson J., Leach L., Michalowski J., Vandergrift S. and Callaway R. (1989) In situ reclamation of spills from underground storage tanks: new approaches for site characterization, project design and evaluation of performance. In Proceedings: Environmental Research Conference on Groundwater Quality and Waste Disposal (Edited by Murarka I. P. and Cordle S.), 2-4 May. Washington, D. C.

Zeyer J. E. P., Kuhn P. and Schwarzenbach R. P. (1986) Rapid microbial mineralization of toluene and 1,3dimethylbenzene in the absence of molecular oxygen. Appl. envir. Microbiol. 52, 944-949.

Zeyer J. E. P., Eicher P., Dolfing and Schwarzenbach R. P. (1990) Anaerobic degradation of aromatic hydrocarbons. In Biotechnology and Biodegradation (Kamely D., Chakrabarty A. and Ormenn G. S.), pp. 33-40. Portfolio, The Woodlands, Tex. 